\title{
Anachelin, the Siderophore of the Cyanobacterium Anabaena cylindrica CCAP 1403/2A ${ }^{\#}$
}

\author{
Hans Beiderbeck ${ }^{\mathrm{a}}$, Kambiz Taraz ${ }^{\mathrm{a}}$, Herbert Budzikiewicz ${ }^{\mathrm{a}, *}$ \\ and Anthony E. Walsby ${ }^{\mathrm{b}}$ \\ a Institut für Organische Chemie der Universität zu Köln, Greinstr. 4, D-50939 Köln, \\ Germany. Fax +49-221-470-5057. E-mail: h.budzikiewicz@uni-koeln.de \\ b School of Biological Sciences, University of Bristol, Woodland Road, Bristol BS8 IUG, \\ UK. E-mail a.e.walsby@bristol.ac.uk \\ * Author for correspondence and reprint requests \\ Z. Naturforsch. 55c, $681-687$ (2000); received May 8, 2000 \\ Anabaena cylindrica, Anachelin, Siderophore
}

A catecholate siderophore - anachelin - has been isolated from the cyanobacterium Anabaena cylindrica CCAP 1403/2A. The central part of the siderophore is a tripeptide consisting of L-Thr, D-Ser and L-Ser. Its C-terminus is linked amidically to a 1,1-dimethyl-3-amino1,2,3,4-tetrahydro-7,8-dihydroxyquinolinium system and its $\mathrm{N}$-terminus to 6-amino-3,5,7-trihydroxyheptanoic acid. The 7-hydroxyl group of the latter is esterified with salicylic acid whose carboxyl group is condensed with the 6-amino group to an oxazoline ring. Anachelin is the first genuine siderophore of a cyanobacterium whose structure has been elucidated.

\section{Introduction}

Cyanobacteria were the first organisms to perform oxygenic photosynthesis and the oxygen they released was probably responsible for changing the Earth's originally reductive atmosphere into an oxidative one. This had a detrimental side effect: iron, necessary for many enzymatic processes and originally readily available in the form of soluble $\mathrm{Fe}^{2+}$ salts, became transformed in scarcely soluble $\mathrm{Fe}^{3+}$ oxide hydrates. To cope with this problem many organisms release iron chelating

\begin{abstract}
Abbreviations: Common amino acids, 3-letter code; TAP, N/O-trifluoroacetyl (amino acid) isopropyl ester; RPHPLC, reversed phase high performance liquid chromatography; GC, gas chromatography; MS, mass spectrometry; ESI, electrospray ionization; MALDI; matrix assisted laser desorption ionization; TOF, time of flight; PSD, post source decay; NMR, nuclear magnetic resonance; COSY, correlated spectroscopy; DEPT, distortionless enhancement by polarization transfer; HMBC, heteronuclear multiple bond correlation; HMQC, heteronuclear multiple quantum coherence; NOE, nuclear Overhauser effect; ROESY, rotating frame nuclear Overhauser and exchange spectroscopy; WATERGATE, water suppression by gradient-tailored excitation; DSS, 2,2-dimethyl-2-silapentane-5-sulfonate; TMS, tetramethylsilane; CCAP, Culture Collection of Algae and Protozoa.
\end{abstract}

\# Part XCI of the series "Bacterial constituents". For part XC see Sultana et al. (2000); for part LXXXIX Münzinger et al. (2000). compounds, called siderophores, which make iron available more or less specifically to the producing species. Cyanobacteria produce catecholate as well as hydroxamate siderophores as was shown by colour reactions (Wilhelm and Trick, 1994; Wilhelm et al., 1996; Wilhelm et al., 1998), but nothing is known about their structures with the exception of the citrate-hydroxamate, schizokinen (Simpson and Neilands, 1976). Interestingly, schizokinen is also produced by other types of bacteria (Mullis et al., 1971; Budzikiewicz et al., 1997), which suggests that the ability to produce this substance is either inherited from a common ancestor or has been acquired, by convergent evolution or gene transfer.

Fogg (1942) demonstrated that the nitrogen-fixing cyanobacterium Anabaena cylindrica Lemm. released nitrogenous substances into its culture medium. Much of the extracellular nitrogen was in the form of peptidic substances, more of which were produced when iron was deficient in the culture medium (Fogg, 1952). Whitton (1965) obtained an extracellular fraction of high molecular mass containing peptides and a brown pigment. Walsby (1974a) isolated the major extracellular pigment-peptide complex in which Ser and Thr formed $>90 \%$ of the amino acid residues and which bound $>10 \%$ of the iron supplied to the culture. This complex appeared to be formed by poly- 
merisation in the light of a smaller molecule that contained 2 Ser, 1 Thr and a colourless fluorescent moiety (Walsby, 1974b). We report here the elucidation of the structure of a siderophore produced by Anabaena cylindrica CCAP 1403/2A, which contains these structural elements (Beiderbeck, 2000).

\section{Materials and Methods}

\section{Instruments and chemicals}

Mass spectrometry: ESI Finnigan-MAT 900 ST; GC/MS Incos 500 (both Finnigan-MAT, Bremen) with Varian (Sunnyvale CA, USA) GC 3400; MALDI Reflex III with SCOUT source (Bruker, Bremen). For MALDI using an $\mathrm{N}_{2}$-laser the sample was added in a matrix: sample ratio of ca. 500:1 to the matrix solution (saturated solution of 4-hydroxy- $\alpha$-cyanocinnamic acid in $0.1 \%$ aqueous $\mathrm{CF}_{3} \mathrm{COOH}$ in $\mathrm{H}_{2} \mathrm{O} / \mathrm{CH}_{3} \mathrm{CN}$ 1:2). $2 \mu \mathrm{l}$ of the solution were applied to the target and allowed to crystallize. The accelerating voltage was $20 \mathrm{kV}$ for normal spectra and $26.3 \mathrm{kV}$ for PSD measurements.

NMR: DRX $500 \quad\left({ }^{1} \mathrm{H} \quad 500,{ }^{13} \mathrm{C} \quad 125 \mathrm{MHz}\right)$ (Bruker, Karlsruhe). Chemical shifts relative to TMS with the internal standard DSS; $\delta$ (TMS) $=$ $\delta$ (DSS) for ${ }^{1} \mathrm{H}, \delta$ (DSS) $=-1.61 \mathrm{ppm}$ for ${ }^{13} \mathrm{C}$. For suppression of the $\mathrm{H}_{2} \mathrm{O}$ signal by the WATERGATE pulse sequence, $10 \mathrm{mg}$ of the sample was dissolved in $0.6 \mathrm{ml} \mathrm{H}_{2} \mathrm{O} / \mathrm{D}_{2} \mathrm{O}$ 9:1.

UV/Vis: Lambda 7 (Perkin-Elmer, Überlingen) $1 \mathrm{mg}$ of the sample was dissolved in $10 \mathrm{ml}$ buffer solution (100 mm, phosphate buffer, $\mathrm{pH} 4.2$ and $\mathrm{NH}_{4} \mathrm{HCO}_{3}$ buffer, $\mathrm{pH}$ 9.0) with the buffer solution used as reference.

Chromatography: Low pressure chromatography columns used included XAD-4 (Serva, Heidelberg), Biogel P-2 (Bio-Rad, Richmond CA, USA), CM-Sephadex C-25 and DEAE Sephadex A-25 (Pharmacia, Uppsala, S), MN-Polyamid SC6 (Machery \& Nagel, Düren); Sep-Pak $\mathrm{RP}_{18}$ cartridges (Waters Millipore, Milford MA, USA); GC/MS: Chirasil-L-Val (Chrompack, Frankfurt); paper chromatography paper type No. 2668 (Schleicher \& Schüll, Dassel).

Chemicals: Water was desalted and distilled twice in a quartz apparatus. Organic solvents were distilled over a column. Reagents were of p. a. quality.

\section{Production and isolation of anachelin (1)}

The strain of Anabaena cylindrica CCAP 1403/ 2A, originally isolated from a pond in Surrey, England (Fogg, 1942), was obtained from the Culture Collection of Algae and Protozoa at Ambleside, UK. It was grown in a Jaworski medium: $1 \mathrm{ml}$ each of the following solutions to be combined and diluted with bidistilled water to a final volume of 1 litre: a) $4.0 \mathrm{~g} \mathrm{Ca}\left(\mathrm{NO}_{3}\right)_{2} \cdot 4 \mathrm{H}_{2} \mathrm{O}$, b) $2.48 \mathrm{~g} \mathrm{KH}_{2} \mathrm{PO}_{4}$, c) $10.0 \mathrm{~g} \mathrm{MgSO}_{4} \cdot 7 \mathrm{H}_{2} \mathrm{O}$, d) $3.18 \mathrm{~g} \mathrm{NaHCO} 3$, e) $0.45 \mathrm{~g}$ EDTAFeNa and $0.45 \mathrm{~g}$ EDTAH $_{2} \mathrm{Na}_{2}$, f) $0.496 \mathrm{~g} \mathrm{H}_{3} \mathrm{BO}_{3}, 0.278 \mathrm{~g} \mathrm{MnCl}_{2} \cdot 4 \mathrm{H}_{2} \mathrm{O}$ and $0.20 \mathrm{~g}$ $\left(\mathrm{NH}_{4}\right)_{6} \mathrm{Mo}_{7} \mathrm{O}_{24} \cdot 4 \mathrm{H}_{2} \mathrm{O}$, g) $0.008 \mathrm{~g}$ cyanocobalamine, $0.008 \mathrm{~g}$ thiamine hydrochloride and $0.008 \mathrm{~g}$ biotin, h) $16.0 \mathrm{~g} \quad \mathrm{NaNO}_{3}, \quad$ i) $\quad 7.2 \mathrm{~g}$ $\mathrm{Na}_{2} \mathrm{HPO}_{4} \cdot 12 \mathrm{H}_{2} \mathrm{O}$, each dissolved in $200 \mathrm{ml} \mathrm{H} \mathrm{H}_{2} \mathrm{O}$. This medium was modified for maximum siderophore production by decreasing the amount of iron-chelate solution e) from $1 \mathrm{ml}$ to $0.025 \mathrm{ml}$. $300 \mathrm{ml}$ of the culture solution in a $500 \mathrm{ml}$ Erlenmeyer flask with indentations was inoculated, the flask was closed with a sterile stopper and shaken for two weeks at $100 \mathrm{rpm}$. Four 5-1 Erlenmeyer flasks containing 3.51 of the culture medium were inoculated with a stock culture (ratio 1:50). The flasks were aerated continuously with sterile air, illuminated with 10,000 lux in a $12 \mathrm{~h}: 12 \mathrm{~h}$ light:dark cycle, and kept at $21^{\circ} \mathrm{C}$ until the end of the exponential growth was reached (ca. 3-4 weeks). To the culture freed from cell material by centrifugation were added $0.1 \mathrm{~g} \mathrm{NaN}_{3}$ (to prevent further cell growth) and $20 \mathrm{ml}$ of a $5 \% \mathrm{Fe}$ (III) citrate solution per litre. The removal of gelatinous polysaccharides was effected by filtration through cotton wool, a paper filter and a glass fibre filter.

The filtrate was adsorbed on a $5 \mathrm{~cm} \times 50 \mathrm{~cm}$ XAD-column. The dark brown adsorbate was washed with $51 \mathrm{NaN}_{3}$ solution $(0.1 \mathrm{~g} / \mathrm{l})$ and with $10 \mathrm{l}$ $\mathrm{H}_{2} \mathrm{O}$ to elute salts and retained polysaccharides, and then desorbed with $1180 \%$ aqueous $\mathrm{CH}_{3} \mathrm{OH}$ and $2 \mathrm{l}$ pure $\mathrm{CH}_{3} \mathrm{OH}$. If the resin remained dark the siderophores were decomplexed with $100 \mathrm{ml}$ of a $4 \%$ oxalate buffer ( $\mathrm{pH} 4.0)$. After washing out salts with $\mathrm{H}_{2} \mathrm{O}$ organic material was desorbed with 11 $80 \%$ and 11 pure $\mathrm{CH}_{3} \mathrm{OH}$. The combined methanol phases were brought to dryness i. v. at $35^{\circ} \mathrm{C}$. The residue was dissolved in a minimal amount of $0.2 \mathrm{M}$ pyridinium acetate buffer ( $\mathrm{pH}$ 5.0) and chromatographed on Biogel P-2 $(6 \times 20 \mathrm{~cm}$, detection at 405 
and $280 \mathrm{~nm}$ ). The brownish-violet main fraction was brought to dryness i. v. at $35^{\circ} \mathrm{C}$ and chromatographed again on DEAE Sephadex $(2.6 \mathrm{~cm} \times 20 \mathrm{~cm}$, detection at $280 \mathrm{~nm}$ ). In this way a negatively charged brown pigment could be removed. The remainder was again brought to dryness as described above and rechromatographed on CM Sephadex $(2.6 \times 30 \mathrm{~cm}$, detection at $280 \mathrm{~nm})$. The brownishviolet main fraction was brought to dryness again and $40 \mathrm{mg}$ fractions were further purified by descending preparative paper chromatography $(15 \times$ $40 \mathrm{~cm}$ ) with $n-\mathrm{C}_{4} \mathrm{H}_{9} \mathrm{OH} / \mathrm{CH}_{3} \mathrm{COOH} / \mathrm{H}_{2} \mathrm{O}$ 90:10:29 $(\mathrm{v} / \mathrm{v})$. The dark violet main fraction $\left(R_{\mathrm{f}} \mathrm{ca} .0 .5\right)$ was cut out and eluted with $\mathrm{H}_{2} \mathrm{O}$ and $0.1 \mathrm{M} \mathrm{NH}_{4} \mathrm{HCO}_{3}$ solution. The eluates were concentrated i. v. and chromatographed on CM Sephadex $(2.6 \times 20 \mathrm{~cm}$, detection at $280 \mathrm{~nm}$ ) to remove contaminants contained in the paper. The siderophore fraction was brought to dryness i. v. and kept at $-25^{\circ} \mathrm{C} .10 \mathrm{l}$ of culture yielded ca. $100 \mathrm{mg}$ of the iron complex.

For decomplexation all glass vessels were rinsed with $6 \mathrm{M} \mathrm{HCl} .15 \mathrm{mg}$ of the ferri siderophore were adsorbed on a SepPak cartridge (rinsed with $5 \mathrm{ml}$ $\mathrm{CH}_{3} \mathrm{OH}$ and activated 4 times with $5 \mathrm{ml} \mathrm{H}_{2} \mathrm{O}$ ) and treated with $5 \mathrm{ml}$ of a $4 \%$ oxalate buffer $(\mathrm{pH} 4.0)$. After washing with $5 \mathrm{ml}$ of $1 \mathrm{M} \mathrm{NaCl}$ and $5 \mathrm{ml} \mathrm{H}_{2} \mathrm{O}$ the free siderophore was desorbed with $5 \mathrm{ml} 80 \%$ and $5 \mathrm{ml}$ pure $\mathrm{CH}_{3} \mathrm{OH}$. The eluate was concentrated i. v. at $30^{\circ} \mathrm{C}$ and lyophilized. In cases where the substance still had a yellowish tinge it was chromatographed on MN-Polyamid and treated as before.

\section{Results}

1 has an absorption maximum at $287 \mathrm{~nm}$ and shoulders at 247 and $305 \mathrm{~nm}$. These values make a 2,3-dihydroxybenzoic acid system unlikely (cf. e.g., Ehlert et al., 1994). The $\mathrm{Fe}^{3+}$ complex shows $\mathrm{pH}$ dependent broad charge transfer bands between 500 and $600 \mathrm{~nm}$. The hypsochromic shift with increasing $\mathrm{pH}$ is reflected in a change of colour from dark violet to pink due to the change of the protonation of phenolic $\mathrm{OH}$ groups. The molecular mass of $\mathbf{1}$ could be determined as $761.3355 \pm$ $0.0026 \mathrm{u}$. This is in excellent agreement with the gross formula $\mathrm{C}_{35} \mathrm{H}_{49} \mathrm{~N}_{6} \mathrm{O}_{13}(761.3357 \mathrm{u})$ corresponding to the structure deduced below. The mass of the $\mathrm{Fe}^{3+}$ complex is $814.4 \mathrm{u}$ corresponding to $\mathrm{M}+{ }^{56} \mathrm{Fe}-3 \mathrm{H}$. Amino acid analysis after total hydrolysis and TAP derivatization on a chiral column (see Briskot et al., 1986 and Mohn et al., 1990) demonstrated that $\mathbf{1}$ contained $\mathrm{D}-$ and L-Ser and LThr. 1 is very sensitive to hydrolysis: an aqueous solution of $\mathbf{1}$ kept at $4{ }^{\circ} \mathrm{C}$ for several days is transformed completely to a product $18 \mathrm{u}$ heavier (2).

Further information regarding the structural elements contained in $\mathbf{1}$ can be gained from NMR data: the basis of this is the unambiguous identification of all ${ }^{1} \mathrm{H}$ - and ${ }^{13} \mathrm{C}$-signals by a combination of homo- and heteronuclear one- and two-dimensional experiments: COSY allows detection of the ${ }^{3} J$-, TOCSY higher $\mathrm{H}, \mathrm{H}$-couplings. HMQC identifies ${ }^{1} J$-C,H, HMBC ${ }^{2} J$ - and ${ }^{3} J$-coupling and thus allows the identification of quaternary $\mathrm{C}$-atoms. $\mathrm{HMBC}$ indicates the number of $\mathrm{H}$-atoms bound to a carbon. Sequence information is obtained by ROESY which correlates spatially close protons and by HMBC correlating carbonyl and amide signals of neighbouring amino acids. To avoid complications arising from the facile hydrolysis of $\mathbf{1}$, structural studies were performed with 2 (see Fig. 1), whose NMR-signals are compiled in Table I.<smiles>CC(O)C(NC(=O)CC(CC(O)C1COC(c2ccccc2O)=N1)OP)C(=O)NC(CO)C(=O)NC(CO)C(=O)NC1Cc2cc(O)c(O)cc2[N+](C)(C)C1</smiles><smiles>C[14CH2]O[14CH2]C(=O)C[C@@H](O)C[C@@H](O)[C@H](CO)NC(=O)c1ccccc1O</smiles>

Fig. 1. Structure of anachelin (1) and of its hydrolysis product (2). 
Table I. ${ }^{1} \mathrm{H}$ and ${ }^{13} \mathrm{C}$ NMR data of $2\left(\mathrm{H}_{2} \mathrm{O} / \mathrm{D}_{2} \mathrm{O} 9: 1,298^{\circ} \mathrm{C}\right)^{\mathrm{a}}$.

\begin{tabular}{lllllllc}
\hline Position & & ${ }^{1} \mathrm{H}$ & ${ }^{13} \mathrm{C}$ & Position & & ${ }^{1} \mathrm{H}$ & ${ }^{13} \mathrm{C}$ \\
\hline Sal & 1 & - & 117.2 & Ser-1 & 1 & - & 173.1 \\
& 2 & - & 157.5 & & 2 & 4.40 & 56.4 \\
& 3 & 6.97 & 117.5 & & 3 & 3.86 & 61.1 \\
& 4 & 7.45 & 134.6 & & $\mathrm{NH}$ & 8.56 & - \\
& 5 & 7.00 & 120.5 & Ser-2 & 1 & - & 172.1 \\
& 6 & 7.77 & 129.2 & & 2 & 4.37 & 56.7 \\
Hep & $\mathrm{CO}$ & - & 170.3 & & 3 & 3.94 & 61.2 \\
& 1 & - & 174.4 & & $\mathrm{NH}$ & 8.62 & - \\
& 2 & $2.02 / 2.29$ & 43.4 & Quin & $1-\mathrm{CH} 3$ & 3.50 & $57.9 / 58.7$ \\
& 3 & 4.09 & 66.6 & & 2 & $3.38 / 3.80$ & 65.1 \\
& 4 & $1.65 / 1.55$ & 40.3 & & 3 & 4.56 & 41.6 \\
& 5 & 4.06 & 68.1 & & 4 & $2.92 / 3.05$ & 30.9 \\
& 6 & 4.21 & 55.0 & & $4 \mathrm{a}$ & - & 120.2 \\
Thr & 7 & 3.72 & 61.9 & & 5 & 6.72 & 116.8 \\
& $6-\mathrm{NH}$ & 8.48 & - & & 6 & - & 144.9 \\
& 1 & - & 173.1 & & 7 & - & 146.6 \\
& 2 & 4.36 & 59.3 & & 8 & 7.05 & 107.9 \\
& 3 & 4.21 & 67.9 & & $8 \mathrm{a}$ & - & 133.4 \\
& 4 & 1.15 & 19.2 & & $3-\mathrm{NH}$ & 8.09 & - \\
& $\mathrm{NH}$ & 8.15 & - & & & & \\
\hline
\end{tabular}

a Sal - salicylic acid unit, Hep - 6-amino-3,5,7-trihydroxyheptanoic acid unit (cf. Fig. 4), Quin - 1,1-dimethyl-1,2,3,4-tetrahydro-7,8-dihydroxyquinolinium unit (cf. Fig. 3).

\section{The tripeptide Thr-Ser-Ser}

The spin systems of the two Ser and of Thr were established by COSY and TOCSY crosspeaks between the respective side-chain $\mathrm{H}$ atoms and that of the proper $\mathrm{NH}$ group; the corresponding $\mathrm{C}$ atoms were identified by HMQC, the $\mathrm{CO}$ groups by HMBC. The shift values indicate that the three amino acids are connected by peptide bonds and especially that the $\mathrm{OH}$ groups are free (ester bonds would result in a downfield shift of ca. $0.5 \mathrm{ppm}$ of the $\beta$-protons; Budzikiewicz, 1997). The sequence Thr-Ser-Ser follows from ROESY experiments (see Fig. 2) and from mass spectral data (see below). The chirality of the three amino acids had been determined (see above) as L-Thr, D-Ser and L-Ser.
The 1,1-dimethyl-3-amino-1,2,3,4-tetrahydro7,8-dihydroxyquinolinium system

The connectivities of the aliphatic part of the molecule were established by COSY cross peaks of $\mathrm{H}-3$ with the neighbouring $\mathrm{CH}_{2}$-groups and with the $\mathrm{NH}$ at $8.09 \mathrm{ppm}$. In the TOCSY experiment the coupling of the $\mathrm{NH}$ proton with the two $\mathrm{CH}_{2}$ groups can also be seen. The corresponding $\mathrm{C}$-resonances were identified by the ${ }^{1} J$ coupling in a HMQC experiment. The proton signals of the two N-methyl groups coincide, but they show ${ }^{1} J$ coupling to two C-atoms at 57.9 and $58.7 \mathrm{ppm}$ and ${ }^{2} J$ coupling to the other ones, respectively; hence, they are both bound to the same atom. The low shift value suggests that it is a strongly electron withdrawing centre. In addition, long-range cou-

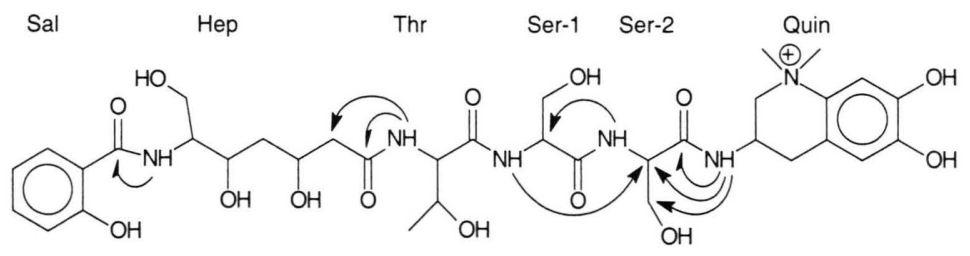

Fig. 2. Sequence relevant cross peaks for 1 derived from ROESY (full arrows) and HMBC (half arrows) experiments. 
pling is observed with the $\mathrm{CH}_{2}$ group at $65.1 \mathrm{ppm}$ (C-2) and an aromatic quaternary $\mathrm{C}$ at $133.4 \mathrm{ppm}$. In the ROESY spectrum cross signals between the $\mathrm{CH}_{3}$ protons and those of the neighbouring $\mathrm{CH}_{2}$ group (C-2) as well as with an aromatic proton at $7.05 \mathrm{ppm}$ can be observed.

The connection of the aliphatic with the aromatic part of the molecule can be deduced from the protons of the $\mathrm{CH}_{2}$ group $\mathrm{C}-4$. They show HMBC connectivities with a $\mathrm{CH}$-carbon (116.8 ppm) and 2 quaternary C-atoms (according to the HMQC and DEPT experiments) at 120.2 and $133.4 \mathrm{ppm}$, the last one in the neighbourhood of the $\mathrm{CH}_{3}$ groups mentioned above, as well as with the $\mathrm{H}$ at $6.72 \mathrm{ppm}(\mathrm{C}-5)$. The connectivities within the aromatic ring can be seen in Fig. 3. The assignment of the respective shift values to the two phenolic carbon atoms could not be deduced from the HMBC experiments as both showed equally strong coupling to the $\mathrm{CH}$ protons at $\mathrm{C}-5$ and C-8. A comparison with the structurally related dihydropyoverdin chromophore (Gwose and Taraz, 1992) suggests the assignment given in Table I, which is in agreement with the more pronounced deshielding of the quaternary $\mathrm{N}^{+}$to the meta as compared with the para position. HMBC and ROESY correlates the $\mathrm{NH}$ signal with the C-terminal Ser (see Fig. 2).

\section{6-Amino-3,5,7-trihydroxyheptanoic acid}

The structural studies of this part of the molecule are complicated by the overlap of the proton $\mathrm{CHOH}$ signals ( $\mathrm{C}-3$ and $\mathrm{C}-5)$ and the coincidence of that of $\mathrm{C}-6$ with the one of the $\beta-\mathrm{CH}$ of $\mathrm{Thr}$ (see Table I). The connectivities of the ${ }^{1} \mathrm{H}$ NMR signals were determined starting from the $\mathrm{CH}_{2}$ protons at C-4 (1.55/1.65 ppm). A TOCSY experiment gave cross peaks with the second $\mathrm{CH}_{2}$ group

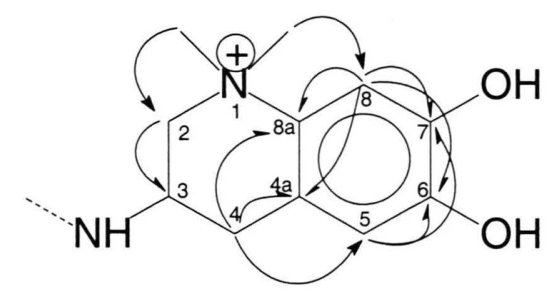

Fig. 3. Selected cross peaks for the dihydroxytetrahydroquinolinium system (ROESY full arrows, HMBC half arrows).
$(2.02 / 2.29 \mathrm{ppm})$ as well as with the two $\mathrm{CHOH}$ groups (4.06 and $4.09 \mathrm{ppm}$ ). The system can be extended by the observation of cross peaks from H-5 to H-6 (4.21 ppm) and from H-6 to H-7 (3.72 ppm), and from the NH-signal at $8.48 \mathrm{ppm}$ to $\mathrm{H}-7$ and $\mathrm{H}-6$. COSY ${ }^{3} J$ couplings confirm the relationships $\mathrm{NH} / \mathrm{H}-6, \mathrm{H}-7 / \mathrm{H}-6$, and show inter alia that the two $\mathrm{CH}_{2}$ groups are not connected with each other.

The $\mathrm{H}$-bearing $\mathrm{C}$ atoms were identified by DEPT and HMQC experiments. C,H-correlations confirmed the structure deduced from the proton spectrum (see Fig. 4). Of special importance is the correlation of the $\mathrm{CO}$ group at $174.4 \mathrm{ppm}$ with the $\mathrm{CH}_{2}$ group $\mathrm{C}-2$ only; this excludes an $\alpha$-hydroxy acid, which might have been expected as a complexing site. HMBC and ROESY data connect the $\mathrm{CO}$ group with the $\mathrm{NH}$ group of Thr.

\section{Salicylic acid part}

The proton spin system corresponds to literature data (Okujo et al., 1994) and could be confirmed by TOCSY, HMQC and HMBC experiments. A HMBC cross peak connects its $\mathrm{CO}$ group with the $\mathrm{NH}$ of the heptanoic acid system.

\section{The additional ring system of $\mathbf{1}$}

The molecular mass of $\mathbf{2}$ is $18 \mathrm{u}$ higher than that of 1. This indicates that during hydrolysis a ring was opened. NMR data were obtained only from mixtures of $\mathbf{1}$ and 2. Changes in the spectra occur only in the salicylic acid/amino-trihydroxyheptanoic acid part of the structure; this can be explained by the formation of an oxazoline ring. Especially evident are the signals at 5.08 ( $\mathrm{H}-6$, now $\mathrm{H}-4$ of the ring) and $5.33 \mathrm{ppm}(\mathrm{H}-7$, now $\mathrm{H}-5$ of the ring). In a $\mathrm{HMBC}$ experiment both couple to $\mathrm{C}-2$ and $\mathrm{C}-4$ of the chain. In the ${ }^{13} \mathrm{C}$ spectrum signals occur at $80.2 \mathrm{ppm}$ (C-7, now C-5 of the ring) showing geminal coupling with the proton signal

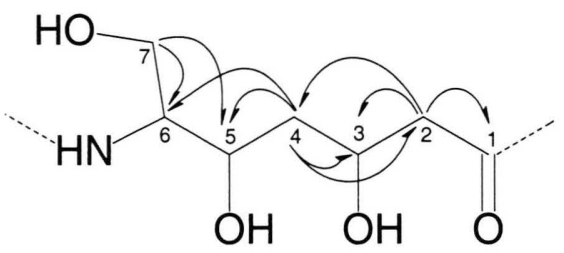

Fig. 4. Selected heteronuclear long-range couplings in the amino-trihydroxy-heptanoic subunit. 
at $5.08 \mathrm{ppm}$, and at $72.3 \mathrm{ppm}(\mathrm{C}-6$, now C-4 of the ring). In the salicylic acid part, the signal of the phenolic carbon (C-2) is shifted to $160.1 \mathrm{ppm}$ and that of the former carboxyl group is now found at $166.8 \mathrm{ppm}$. These values agree well with those obtained from other siderophores containing the 2-o-hydroxyphenyl-oxazoline substructure (Okujo et al., 1994). The signals of Thr as the next unit show only minute shifts.

\section{Sequence of the subunits}

Cross peaks relevant to the connections between the structural subunits were mentioned in the preceding sections and are combined in Fig. 2. The sequence is confirmed by characteristic fragments observed in a MALDI-TOF-PSD mass spectrum (Tang et al., 1988; Spengler et al., 1992). The B- $\left(\mathrm{R}-\mathrm{CO}^{+}\right)$and $\mathrm{Y}^{\prime}$-ions $\left(\mathrm{H}_{2} \mathrm{~N}-\mathrm{R}^{\prime}\right)$ (Roepstorff and Fohlman, 1984) formed by cleavage of the amide bonds are depicted in Fig. 5. They are accompanied by ions formed by the loss of $\mathrm{H}_{2} \mathrm{O}$. Of interest are two ions $(\mathrm{m} / z 236$ and 256) which are formed by a McLafferty rearrangement of the $\beta$-hydroxycarbonyl unit. The stereochemistry of most of the chiral centres remains to be determined.

\section{Discussion}

The structure of anachelin (1) from Anabaena cylindrica differs considerably from those obtained so far from other bacteria although it is typical in its use of the catecholate and the 2-o-hydroxyphenyloxazoline system for binding $\mathrm{Fe}^{3+}$. It is the combination of structural elements that makes the structure unique. The discovery of this novel structure suggests that cyanobacteria independently evolved their own siderophores. Anachelin contains only the two binding sites for $\mathrm{Fe}^{3+}$ mentioned above. In the ESI-MS spectrum only an ion for a 1:1 complex $\left(\left[\mathbf{1}-3 \mathrm{H}^{+}+\mathrm{Fe}^{3+}\right]^{+}\right)$can be observed. In such cases the two remaining coordination sites of $\mathrm{Fe}^{3+}$ are usually occupied by two molecules of $\mathrm{H}_{2} \mathrm{O}$ (Scarrow et al., 1991).

Nothing is known about the mechanisms of the iron transport into the cell and the intracellular release in cyanobacteria. For Synechococcus a socalled taxi mechanism has been proposed: $\mathrm{Fe}^{3+}$ is transported by a hydroxamate siderophore to the cell surface and transferred there to a catecholate siderophore. In this way only a biosynthetically less costly hydroxamate (as, e.g., schizokinen) is lost in part by diffusion, an advantage in the aquatic realm (Wilhelm et al. 1994; Wilhelm et al.,

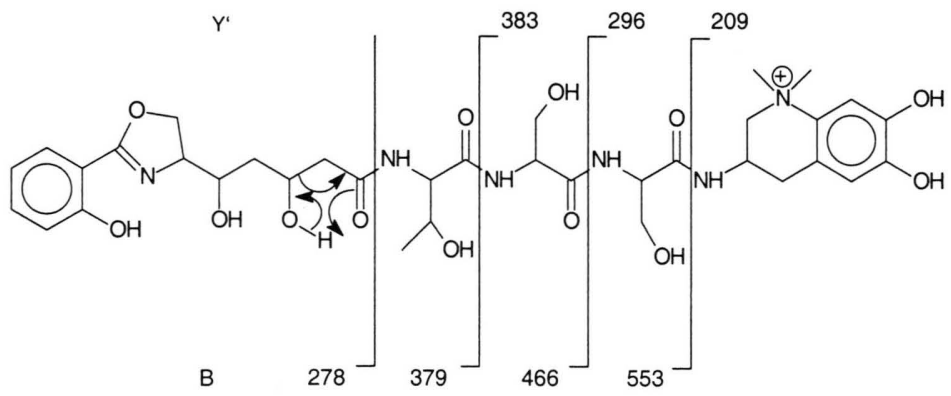<smiles>C=C(O)NC(C(=O)NC(CO)C(=O)NC(CO)C(=O)NC1Cc2cc(O)c(O)cc2N(C)C1)C(C)O</smiles>

Fig. 5. Characteristic fragments in the MALDI-TOF mass spectrum of $\mathbf{1}$. 
1996). In eubacteria iron is released from its siderophore by reduction to $\mathrm{Fe}^{2+}$. Since the redox potential of complexed $\mathrm{Fe}^{3+}$ in most siderophores is much too negative for a reduction in the equilibrium state by biological reducing agents as $\mathrm{NADH}, \mathrm{Fe}^{2+}$ must be removed by complexation in, e.g., porphyrins. This renders according to the

Beiderbeck H. (2000), Anachelin, ein Siderophor vom Catecholat-Typ aus Anabaena cylindrica CAPP 1403. Dissertation Universität zu Köln. Wissenschaftliche Monographien, Chemie Vol. 4. Blunk, Berlin.

Briskot G., Taraz K. and Budzikiewicz H. (1986), Siderophore vom Pyoverdin-Typ aus Pseudomonas aeruginosa. Z. Naturforsch. 41c, 497-506.

Budzikiewicz H. (1997), Siderophores from fluorescent Pseudomonas. Studies in Natural Products Chemistry (Atta-ur-Rahman, ed.), Elsevier, Amsterdam; vol. 19, $793-835$.

Budzikiewicz H., Münzinger M., Taraz K. and Meyer J.-M. (1997), Schizokinen, the siderophore of the plant deleterious bacterium Ralstonia (Pseudomonas) solanacearum ATCC 11696. Z. Naturforsch. 52c, 496-503.

Crumbliss A. L., Boukhalfa H., Spasojević I., Wirgau J. I. and Stevens R. D. (2000), Mechanisms of ironsiderophore chelation and dechelation reactions. $2^{\text {nd }}$ International Biometals Symposium "Biometals 2000”, Tübingen, 24.-29. April.

Ehlert G., Taraz K. and Budzikiewicz H. (1994), Serratiochelin, a new catecholate siderophore from Serratia marcescens. Z. Naturforsch. 49c, 11-17.

Fogg G. E. (1942), Studies on nitrogen fixation by bluegreen algae. I. Nitrogen fixation by Anabaena cylindrica Lemm. J. Exp. Biol. 19, 78-86.

Fogg G. E. (1952), The production of extracellular nitrogenous substances by a blue-green alga. Proc. R. Soc. B. 139, $372-397$.

Gwose I. and Taraz K. (1992), Pyoverdine aus Pseudomonas putida. Z. Naturforsch. 47c, 487-502.

Mohn G., Taraz K. and Budzikiewicz H. (1990), New pyoverdin-type siderophores from Pseudomonas fluorescens. Z. Naturforsch. 45b, 1437-1450.

Mullis K. B., Pollack J. R. and Neilands J. B. (1971), Structure of schizokinen, an iron transport compound from Bacillus megaterium. Biochemistry 10, 48944898.

Münzinger M., Budzikiewicz H., Expert D., Enard C. and Meyer J.-M. (2000), Achromobactin, a new citrate siderophore of Erwinia chrysanthemi. Z. Naturforsch. 55c, 328-332.

Okujo N., Saito M., Yamamoto S., Yoshida T., Miyoshi S. and Shinoda S. (1994), Structure of vulnibactin, a new polyamine-containing siderophore from Vibrio vulnificus. BioMetals 7, 109-116.

Pierre J. L. and Fontecave M. (1999), Iron and activated oxygen species in biology: The basic chemistry. BioMetals 12, 195-199 (1999).
Nernst equation the redox potential more positive (Pierre and Fontecave, 1999). The same effect is achieved by replacing one of the bidentate siderophore ligands of $\mathrm{Fe}^{3+}$ by $2 \mathrm{H}_{2} \mathrm{O}$ (Crumbliss et al., 2000). This would explain why 1 contains an oxazoline ring that is not very resistant to hydrolysis.
Roepstorff P. and Fohlman J. (1984), Proposal of a common nomenclature for sequence ions in mass spectra of peptides. Biomed. Mass Spectrom. 11, 601.

Scarrow R. C., Ecker D. J., Ng Ch., Liu S. and Raymond K. N. (1991), Coordination chemistry of linear dihydroxyserine (sic!) compounds derived from enterobactin. Inorg. Chem. 30, 900-906.

Simpson F. B. and Neilands J. B. (1976), Siderochromes in cyanophyceae: isolation and characterization of schizokinen from Anabaena sp. J. Phycol. 12, 44-48.

Spengler B., Kirsch D., Kaufmann R. and Jaeger E. (1992), Peptide sequencing by matrix-assisted laser desorption mass spectrometry. Rapid Commun. Mass Spectrom. 6, 105-108.

Sultana R., Siddiqui B. Sh., Taraz K., Budzikiewicz H. and Meyer J.-M. (2000), A pyoverdin from Pseudomonas putida with a Lys $\varepsilon$-amino link in the peptide chain. BioMetals, in press.

Tang X., Ens W., Standing K. G. and Westmore J. B. (1988), Daughter ion mass spectra from cationized molecules of small oligopeptides in a reflecting time-offlight mass spectrometer. Anal. Chem. 60, 1791-1799.

Walsby A. E. (1974a), The extracellular products of Anabaena cylindrica Lemm. I. Isolation of a macromolecular pigment-peptide complex and other components. Brit. Phycol. J. 9, 371-381.

Walsby A.E. (1974b), The extracellular products of Anabaena cylindrica Lemm. II. Fluorescent substances containing serine and threonine, and their role in extracellular pigment formation. Brit. Phycol. J. 9, 383-391.

Whitton B. A. (1965), Extracellular products of bluegreen algae. J. Gen. Microbiol. 40, 1-11.

Wilhelm S. W., MacAuley K. and Trick C. G. (1998), Evidence for the importance of catechol-type siderophores in the iron-limited growth of a cyanobacterium. Limnol. Oceanogr. 43, 992-997.

Wilhelm S. W., Maxwell D. P. and Trick C. G. (1996), Growth, iron requirement, and siderophore production in iron-limited Synechococcus PCC 7002. Limnol. Oceanogr. 41, 89-97.

Wilhelm S. W. and S. G. Trick (1994), Iron-limited growth of cyanobacteria: Multiple siderophore production is a common response. Limnol. Oceanogr. 39, 1979-1984. 